\title{
Jesus Christ as the Final Scapegoat: Mobilizing Nonviolent Movements for Change
}

\author{
Craig L. Nessan ${ }^{*}$
}

We live in an age of endemic violence. Violence is fed by the binary categories through which human beings interpret the world, leading to the phenomenon of scapegoating violence. Jesus died to be the final scapegoat. Spirals of fear singled out Jesus to be the scapegoat for the anxieties and animosities of the people in his time. René Girard discovered in the Christian Gospels a truthful narrative that did not mask or disguise scapegoating for what it is: the elimination of the innocent victim(s). Christians dare to claim that Jesus died to end all scapegoating. This nonviolent interpretation of the cross of Jesus Christ serves as the theological foundation for active participation by Christians in movements for organized nonviolent resistance as a means of achieving social justice. This foundation is urgently needed in a world of spiraling violence and war making.

Keywords: advocacy, binary, civil resistance, cross, Girard, mimesis, nonviolence, reconciliation, scapegoat theory, violence

We live in an age of endemic violence: domestic violence in the home, violent crime on the streets, terrorist violence against innocents, and military violence between nations. In many instances people and nations would resort to violence as the first response in dealing with serious disputes. In the United States, there is a deeply ingrained and widely disseminated "myth of redemptive violence" that sees violence as the first resort for addressing intractable conflicts. ${ }^{1}$

In a violent world, where do Christians locate themselves in relationship to the Prince of Peace who proclaimed, "Blessed are the peacemakers" (Mt 5.9) and "Love your enemies" (Mt 5.44)? Dare we believe that the cross of Jesus Christ is sufficient to accomplish the reconciliation which Paul describes in 2 Corinthians 5 ? Can the cross really make a difference in relationship to the political, socio-economic, and interreligious conflicts faced by the church and society in our time?

It belongs to the history of human beings that we interpret the world in binary categories, primordially as self-other, us-them, safe-dangerous. While such binary calculations may have contributed to human survival

\footnotetext{
Craig L. Nessan, Academic Dean and Professor of Contextual Theology and Ethics at Wartburg Theological Seminary. Address: Wartburg Theological Seminary 333 Wartburg Place, Dubuque, Iowa 52003, U.S.A. E-Mail: cnessan@wartburgseminary.edu.

1 Walter Wink, "Facing the Myth of Redemptive Violence", in: Ekklesia, http://www.ekklesia.co.uk/content/cpt/article_060823wink.shtml, viewed on February 15, 2012.
} 
under the conditions of a threatened existence in our evolutionary past, such binary thinking now has become itself a threat to human existence. Rosemary Radford Ruether has analyzed how dualistic thinking permeates philosophical discourse (subject-object, reason-emotion, individual-community, immanence-transcendence) and religious discourse (sacred-secular, soul-body, spirit-matter, good-evil). ${ }^{2}$ Dualistic thinking based on binary categories leads inexorably into hierarchical structures of domination and subjugation: male-female, rich-poor, old-young, white-black, hetero-homo, abled-disabled, human-creation, in group-out group. We understand ourselves in terms of "I am this, not that." Dualistic thinking according to binary categories undergirds all forms of structural injustice: the „isms.”3

Fear is a primal response, originating as a survival mechanism, which in humans can be agitated or assuaged through symbolic speech and symbolic actions. The human condition is a fearful thing. While many agitate using fear, Jesus assuaged fear. There are many reasons why Jesus so frequently proclaimed the Gospel to his followers saying, „Do not be afraid.” Fear does not remain self-contained. Fear is contagious. Human fears coalesce to form swirling spirals. Girard names this mimetic desire, which issues forth in mimetic rivalry. Human beings learn by imitation. As creatures highly influenced by our surrounding culture, we have the capacity to imitate the beautiful and noble and the capacity to imitate the ugly and dishonorable. When fear takes over, we join our anxieties together in spirals of fear, looking for a target. The way human groups deal with collective anxiety is by finding someone to blame: scapegoating. What is insidious about scapegoating, according to Girard, is that it remains hidden from our own eyes. We do not recognize what we are doing when we scapegoat. We are convinced „they” are only getting what they deserve.

\section{Girard and the Scapegoat Mechanism}

One of the most fascinating interpreters of the cross, articulating its implications for peacemaking and the ministry of reconciliation, is René Girard. Girard began his career as an interpreter of literature, ancient mythology, and ethnography, teaching in France and the United States. What fascinated Girard in the literature, stories, and cultures he investigated was how one particular pattern repeated itself over and over again. This pattern involved the identification, blaming, and violence against a particular victim. Over his career Girard developed an elaborate theory about the human propensity

\footnotetext{
2 Rosemary Radford Ruether, Liberation Theology: Human Hope Confronts Christian History and American Power, New York, Paulist 1972, p. 6, 255-256.

3 Ibidem.
} 
for scapegoating violence as one of the most characteristic of all human activities. In elaborating the meaning of the cross for the ministry of reconciliation in a violent world, this article draws upon the work of Girard to argue that the church, in obedience to the cross, must serve as an agent for peace and reconciliation in our contemporary society and world.

Girard explores at length how human beings inevitably engage in the behavior of imitation. For example, children learn how to speak and how to act by imitating others. The entire process of human socialization within a particular culture involves an elaborate and comprehensive process of imitation, what Girard calls mimesis. Mimesis pervades human existence, even among adults. Advertising, for example, cleverly instills mimetic desire into human hearts and minds to form them as consumers, so they will desire and buy particular goods and services. As a pertinent instance, when I mention to my students a particular author or book that I find significant, many of them also will begin to desire to read or own this book. Imitation or mimesis is so omnipresent in human life that we scarcely recognize how pervasively it influences our behavior.

In itself mimesis is not a problem for human existence. Mimesis is natural and inevitable. An acute problem arises, however, in that mimesis regularly degenerates into competition and rivalry between persons and groups. For example, whenever there is a scarcity of resources (say, water or land), it is predictable that those dependent on these resources begin to compete and become rivals for these limited resources, a scenario that is manifest across the globe. In the case of children, for example, competition and rivalry easily devolve into which of them is the best at playing a particular game. In the case of adult society, men easily become competitors and rivals for the affection of a particular woman - an example that is all too common in many different cultures and tragically resulting in violence. ${ }^{4}$ Even in the church there emerges competition and rivalry for certain proposals, jobs, calls, or positions, resulting in bitter conflict. Also between religions, for example Christianity and Islam, members of these faith traditions become swept up into rivalry and competitors for success in influencing the population and society. While mimesis is a natural and inevitable aspect of human existence, it easily degenerates into competition and rivalry, leading to anxiety and tension among the contesting parties and affecting human community.

The next step in Girard's theory involves "the scapegoat mechanism." How do individuals and groups inevitably deal with the anxiety and tension that emerges from mimetic rivalry? There is one predictable occurrence. In-

4 John Archer, "Power and Male Violence", in: John Archer (ed.), Male Violence, New York, Routledge 1994. 
dividuals and groups identify someone to blame for their problems. After a really difficult day, one goes home and vents frustration against a child or a spouse. In the church, particular members become identified as those who are the cause of all the problems. Often the identified scapegoat is a person or group which does not easily assimilate into the larger society. This could be a non-conformist of some kind. Or, it could be those who are easily singled out as different from the majority, identifiable by color, ethnicity, class, language, culture, beliefs, or some other readily recognizable characteristic. Families sometimes identify a particular family member to blame for their problems. Churches begin to focus on an internal or an external enemy. Societies focus on those who do not or choose not to fit in to the cultural norms. Nations identify other nations as part of an "evil empire."

In a further complication to Girard's scapegoat theory, those who identify a person or group as responsible for their problems in every instance maintain the deep and abiding conviction that they are entirely justified in singling out the scapegoat as blameworthy. The accusers always assert that the scapegoat is only receiving what he/she/they deserve(s). The fact that they are repeating the ancient mechanism of scapegoating is hidden from their awareness. They remain absolutely convinced that they are fully justified and righteous in carrying out their accusations, blame, exclusion, and ultimately violence against the identified scapegoat. Scapegoats are understood as having brought the trouble upon themselves. Decent society is only giving them what they deserve based on their behavior and differentness.

Once a society executes scapegoating against the identified victim (whether an individual or group), the accumulated tension and anxiety of that society is released - at least for a period of time. In this sense, scapegoating discharges the buildup of social angst and desire for vengeance. Scapegoating relieves collective tension. A kind of purification takes place. However, scapegoating only eases the anxiety for a limited period of time. All too soon, new anxieties and tensions once more begin to mount. Once again there emerges the need to identify new scapegoats, who in due time also will need to be eliminated for the good of the group or society. This cycle repeats itself endlessly, a story as old as the history of the world. ${ }^{5}$

Girard documents the scapegoating mechanism with reference to countless instances in ancient mythology, literature, and cultural anthropology. ${ }^{6} \mathrm{He}$ goes so far as to claim that all religions and every human culture originate through the ritual practice of scapegoating, by means of various

\footnotetext{
5 See: René Girard, Things Hidden since the Foundation of the World, New York, Continuum 2003.

6 R. Girard, The Girard Reader, edited by James G. Williams, New York, Crossroad 1996.
} 
forms of sacrifice, including primordially the practice of human sacrifice. Over the generations, however, the truth about human sacrifice and scapegoating become masked as the story is handed down. A figure that once functioned as scapegoat typically becomes valorized in later narratives as a hero or even a god. Human societies are knit closely together by their mutual participation in the identification, blaming, and eradication of scapegoats. Social bonding occurs in a profound way among those who have conspired, even unaware, to eliminate an enemy of society from their midst.

\section{The Crucifixion of Jesus and the End of Scapegoating}

What makes Girard's work so significant for theology and the life of the church and its ministry of reconciliation is his analysis of the New Testament, in particular his interpretation of the Christian passion narratives. Girard's own return to active profession of Christian faith took place as a result of his discovery in the Gospels of the unambiguous disclosure of the scapegoat mechanism for what it truly is: the identification, execution, elimination, and death of an innocent victim. The crucifixion of Jesus transpired as a consequence of mimetic rivalry - jealousy and fear among those who defined him as a danger and enemy to the people. Unlike other cultural or religious narratives, however, in the Gospel narrative, Jesus is consistently affirmed as entirely innocent. In fact, the Christian story maintains that Jesus "knew no sin" (2 Cor. 5.21). The Christian account from beginning to end contends that Jesus did not deserve what he received, grave mistreatment and death on the cross. In human terms, the Gospel narratives expose the crucifixion as the consequence of unjustified suspicion, resentment, and sin against Jesus. Jesus did not get what he deserved. He was wrongly accused, blamed, condemned, and executed.

Girard maintains that for the first time in human history the truthfulness of the Christian passion stories fully reveal the scapegoat mechanism for what it is. Because of this insight and its significance for unmasking the universal scapegoat mechanism, Girard returned to the Christian faith. Thereby his career shifted from analyzing the phenomenon of scapegoating in human societies to the criticism and overcoming of the reality of sacred violence with reference to the crucifixion of Jesus. One might describe Girard's foundational insight in this way: Of all people on earth, Christians are those called to recognize and name scapegoating for what it is, in order that it might cease to have its mystifying power over us. Christians are those who ought to know better than to identify and project blame on ever new scapegoats. Christians are those people on earth who, for Jesus' sake, are called to announce a prophetic "No!" against every situation where tension 
and anxiety are spiraling out of control, before they lead to the execution and elimination of new scapegoats.

This understanding of the cross summons the church of Jesus Christ to a profound vocation in a world of violence. Because Jesus Christ died to be the final scapegoat, Christians are called to resist the phenomenon of scapegoating violence in all its guises. What human authorities and the mob intended for evil - the crucifixion of Jesus Christ - God turns upside down. God allowed Jesus to act as the final scapegoat, in order that our proclivity for scapegoating might be exposed for all to see and thereby be unmasked and undone. For Jesus' sake, let there be no more scapegoats!

What are the implications for the church of Jesus Christ in its ministry of reconciliation? It means we must remain vigilant in all situations of human conflict that normally and inevitably would degenerate into enmity through the contagion of mimetic rivalry. It means the church must sound a warning whenever threats of violence escalate against an identified scapegoat as the victim. It means that the church keeps reminding itself that Jesus Christ died to be the final scapegoat, whenever it would engage internally in scapegoating behaviors against members of its own community. And it means that the church is called to serve as an advocate in society for curbing the mania of mimetic rivalry, competition, and threats of scapegoating violence wherever it threatens to erupt. God on the cross made Jesus to be sin, the innocent victim of human scapegoating, in order that by his death the Christian church becomes the righteousness of God in the world. We are the righteousness of God in the world through our resistance to the allure of scapegoating violence against others, serving God's way of peacemaking and reconciliation.

\section{Nonviolent Advocacy for Change}

Arguably, the most important innovation in the entire 20th century was the emergence of nonviolent direct action to accomplish political change. Mohandas Gandhi, Martin Luther King, Jr., and Desmond Tutu each were at the forefront of movements employing nonviolent methods to unmask before the world an unjust status quo and to organize provocative yet peaceful direct action to accomplish social change and establish a new political order.

Evidence for the effectiveness of nonviolent civil resistance to accomplish change and establish the conditions for lasting peace continues to accumulate and needs to become well known. The research of Erica Chenoweth and Maria J. Stephan published as Why Civil Resistance Works: The Strategic Logic of Nonviolent Conflict examines with factor analysis 323 violent and 
nonviolent resistance campaigns between 1900 and 2005, including four case studies in greater detail. One of these primary cases involved the first Palestinian intifada, 1987-1992, whose success was compromised by the simultaneous inclusion of violent elements. ${ }^{7}$

The most striking finding is that...nonviolent resistance campaigns were nearly twice as likely to achieve full or partial success as their violent counterparts....Among the 323 campaigns, in the case of antiregime resistance campaigns, the use of nonviolent strategy has greatly enhanced the likelihood of success. Among campaigns with territorial objectives, like antioccupation or self-determination, nonviolent campaigns also have a slight advantage. Among the few cases of major resistance that do not fall into either category (antiapartheid campaigns, for instance), nonviolent resistance has had the monopoly on success. ${ }^{8}$

The one exception to the preferential success of methods of nonviolent resistance are those cases involving succession, although in those 41 cases violent succession campaigns also are infrequently successful (only 4 of 41). Succession campaigns are on the whole severely compromised wherever a particular regime is sponsored politically and militarily by a powerful foreign nation.

The aim of successful nonviolent campaigns is to attain „a shift in power between the opposition and the adversary. Resilience involves increasing mobilization and action, maintaining key assets and resources, and bringing a diverse constellation of assets and tactics to bear against the adversary, regardless of whether the adversary is materially more powerful." Successful nonviolent campaigns generate mass mobilization with diversity among their participants, which provokes increasing alienation between the regime and its main pillars of support, including members of the security forces. ${ }^{10}$ Repressive measures by a regime against nonviolent participants can „backfire” against that regime, accelerating such alienation. ${ }^{11}$ The larger the number of participants in a nonviolent resistance movement contributes to the probability of that movement's success. That being said, it is much easier to mobilize a larger number of participants for nonviolent rather than violent campaigns. ${ }^{12}$ It is extremely important to note that nonviolent civil

Erica Chenoweth, Maria J. Stephan, Why Civil Resistance Works: The Strategic Logic of Nonviolent Conflict, New York, Columbia University 2011, p. 146.

$8 \quad$ Ibidem, p. 7.

9 Ibidem, p. 58.

10 Ibidem, p. 192-193.

11 Ibidem, p. 50-51.

12 Ibidem, p, 30. 
resistance establishes the conditions for democracy and a lasting peace far more effectively than violent campaigns. ${ }^{13}$

One particular experiment in nonviolent truth and reconciliation has been documented in the film, „Reunion: Dialog and Reconciliation in Kosovo." ${ }^{14}$ By the mediation of the Nansen Dialogue Network as facilitated by Steinar Bryn, young Serbs and Albanians were brought together out of the violent conflict between their peoples toward the goal of attaining deeper understanding of the other. Through the organization of a process built on listening and the sharing painful stories, the viewer witnesses the way for alienated parties to arrive both at clearer self-recognition and acknowledgement of the legitimacy of another's grievances. Though the path is strewn with resentment, resistance, and many serious obstacles, building human relationships among those most affected by a deep and traumatic divide offers hope for the emergence of another path into the future. Such grassroots initiatives provide genuine hope for catalyzing human communities to strategize and organize effectively in implementing lasting, nonviolent movements for change.

The nonviolent interpretation of the cross of Jesus Christ serves as the theological foundation for active participation by Christians in movements for organized nonviolent resistance as a means of achieving social justice. This foundation is urgently needed in a world of spiraling violence and war making.

\footnotetext{
13 Ibidem, p. 218-219.

14 The international title is Reunion - Ten Years after the War, directed by Jon Haukeland, Norwegian Film Institute, 2011. Another extremely fruitful film for stirring new imagination is The Power of Forgiveness, directed by Martin Doblmeier, Journey Films, 2008.
} 